\title{
Diversity of ectomycorrhizal fungus assemblages on nursery grown European beech seedlings
}

\author{
Marcin Pietras • Maria Rudawska • Tomasz Leski • \\ Leszek Karliński
}

Received: 4 June 2012 / Accepted: 28 August 2012 /Published online: 18 September 2012

(C) The Author(s) 2012. This article is published with open access at Springerlink.com

\begin{abstract}
- Context An important feature of forest nursery management is the production of first-rate planting stock, which is closely connected with an adequate development of ectomycorrhizas on seedling roots.

- Aims The aim of this study was to provide a detailed assessment of the ectomycorrhizal (ECM) fungal diversity of European beech grown in bare-root forest nursery conditions.

- Methods Morphological and molecular analyzes were used to identify ECM fungi, quantify fungal richness, and record differences in the relative abundance of individual taxa.

- Results Twenty-seven different mycorrhizal fungal taxa were found in four tested nurseries. Of these 27, only 6 were present in more than one nursery. Taxa richness in individual nurseries ranged from 6 to 13 , indicating that ECM colonization potential is nursery-dependent. The most frequent taxa were: Tuber sp. 1, Cadophora sp., Cenococcum geophilum agg., Hebeloma sacchariolens, and Laccaria tortilis. According to the analysis of
\end{abstract}

Handling Editor: Ana Rincon

Electronic supplementary material The online version of this article (doi:10.1007/s13595-012-0243-y) contains supplementary material, which is available to authorized users.

Contribution of the co-authors Marcin Pietras: experimental design, data collection, data analysis, writing the paper

Maria Rudawska: experimental design, internal reviews, intermediate reviews, writing the paper, coordinating the research project Tomasz Leski: collaboration in experimental design, data analysis, writing the paper

Leszek Karliński: collaboration in data analysis

M. Pietras · M. Rudawska $(\bowtie) \cdot$ T. Leski $\cdot$ L. Karliński

Laboratory of Mycorrhizal Research, Institute of Dendrology

Polish Academy of Sciences,

Parkowa Str. 5,

62-035 Kórnik, Poland

e-mail: mariarud@man.poznan.pl similarity, ECM fungal communities were significantly different between nurseries $(R=0.7741 ; p<0.0001)$.

- Conclusion Beech seedlings grown in bare-root nurseries are colonized by a highly diverse suite of ECM fungi; thus, artificial inoculation of seedlings is generally not necessary in nursery practice.

Keywords Ectomycorrhizal diversity · Forest nursery · Molecular identification · Fagus sylvatica

\section{Introduction}

European beech (Fagus sylvatica L.) is a widespread species of ecological and economic importance in Europe. Its geographical distribution is extensive; from $60^{\circ} 78^{\prime}$ in the north, to $37^{\circ} 78^{\prime}$ in the south. It has a high tolerance to shade and is able to thrive in a wide variety of soil types, topographical positions, and climatic conditions (Diekmann et al. 1999). As a result of forest management practices in recent decades, there is a tendency for conifers to dominate in forests within the natural distribution area of the European beech (Moosmayer 2002). In Poland, beech covers less than 4.2\% of the forested area. One of the aims of current forest management policy is to give priority to promoting both the natural regeneration and deliberate afforestation of deciduous trees (mainly oaks and beech) to increase the forested area. Natural regeneration of beech in Poland is rather scarce, because of its irregular distribution and an insufficient total area of mature beech stands. Hence, beech seedlings are grown for 2 to 3 years in forest nurseries in order to establish new stands more effectively. In Polish bare-root nurseries, beech seedlings constitute the third (after oaks and birch) most highly grown deciduous tree species (almost 140 million seedlings per year). A fundamental feature of forest nursery management is the production of first-rate 
planting stock of appropriate: plant height, diameter, shoot biomass, and root system quality. Most of these attributes are closely connected with the adequate development of ectomycorrhizas on the seedling roots (Dahlberg and Stenström 1991). The role of diverse ectomycorrhizal (ECM) inoculum already developed in the nursery, also seems to be an important contributor to the survival potential of seedlings after outplanting to forest sites (Jones et al. 2003). Ectomycorrhizal fungi facilitate nutrient and water supply to the plants, and enhance vitality, so that plants can better resist pests, pathogens, and climatic stress (Perry et al. 1987). In common with most European temperate forest tree species, European beech is in natural condition obligatorily associated with ECM fungi (Meyer 1973). The first description of beech-mycorrhizal symbiosis was presented by Frank (1885). More detailed observations of the morphology and anatomy of beech mycorrhizas were provided by Harley (1959). For several years, studies on the ECM communities of beech trees have focused on surveying old forest stands and natural regeneration areas, basing results on observations of fruiting bodies or superficial morphotyping (Dominik 1957; Dominik and Boullard 1961; Voiry 1981). In recent years, the development in sampling techniques and methods of identification of ECM fungi, have resulted in a more comprehensive description of the characteristics of ECM beech morphotypes. Detailed descriptions of the morphology and anatomy of 23 fungal taxa was revealed by Agerer (1987-2008). PCR-based molecular methods and DNA sequencing have been used to identify mycorrhizal fungi for the last 20 years as a matter of routine, and have led to a greater understanding of the composition and structure of the ECM fungal communities of beech in mature forests (Buée et al. 2005; Grebenc and Kraigher 2007; Grebenc et al. 2009; Pena et al. 2010), or on young trees in natural conditions or in pot experiments (Železnik et al. 2007; Druebert et al. 2009; Pritsch et al. 2009). These studies revealed remarkable below-ground ECM fungal taxa richness (16 to 89 taxa), depending on the beech age, and site or experimental conditions. However, apart from preliminary studies based only on morphotyping (Rudawska and Leski 2009), no detailed information is available about the ECM fungal community structure of beech seedlings in the semi-artificial conditions of forest nurseries. To fill this important gap in our knowledge, we used molecular analysis to identify beech seedling symbionts, to quantify the ECM fungal richness, and to record differences in the relative abundance of individual taxa. We present our results in the context of our and other authors' recent works, describing the ECM fungal community structure of coniferous and deciduous tree species grown in the forest nurseries.

\section{Materials and methods}

\subsection{Nurseries and sampling of seedlings}

Four bare-root nurseries belonging to the forest districts in north-western (Susz-SUSZ 53 44' N, 19 33' E; RunowoRUN $5319^{\prime} \mathrm{N}, 1729^{\prime}$ E), central (Piaski-PIA $5158^{\prime} \mathrm{N}, 17$ $01^{\prime} \mathrm{E}$ ) and south-western (Prudnik-PRU $5027^{\prime} \mathrm{N}, 1746^{\prime} \mathrm{E}$ ) Poland were analyzed. The examined nurseries were situated in regions with a mean annual temperature ranging from 7.4 to $8.1{ }^{\circ} \mathrm{C}$, and a mean annual precipitation of between 510 and $605 \mathrm{~mm}$, with the exception of the PRU nursery, which was located in a mountainous area where higher mean annual precipitation $(800 \mathrm{~mm})$ was noted. The chosen nurseries have been established on sites previously covered by mixed deciduous forests and constituted rather large areas; ranging in size from 3 to 8 ha, and separated into several compartments each with four to five standard nursery seedbeds. Beech seedlings were machine precisionseeded (approx. 250 seeds $/ \mathrm{m}^{-2}$ of seedbed in 5 rows) and were fertilized in accordance with an individual schedule designed for each nursery to maintain adequate fertility in bare-root nursery soils, and to obtain high-quality planting stock (pre-sowing application: $15.0-30.0 \mathrm{~N} \mathrm{~kg} \mathrm{ha}^{-1}, 0.0-5.0$ $\mathrm{P} \mathrm{kg} \mathrm{ha}^{-1}, 25.0-35.0 \mathrm{~K} \mathrm{~kg} \mathrm{ha}^{-1}$, post-sowing application: $20.0-40.0 \mathrm{~N} \mathrm{~kg} \mathrm{ha}^{-1}, 0.0-5.0 \mathrm{P} \mathrm{kg} \mathrm{ha}{ }^{-1}, 35.0-45.0 \mathrm{~K} \mathrm{~kg}$ $\mathrm{ha}^{-1}, 10.0-20.0 \mathrm{Mg} \mathrm{kg} \mathrm{ha}{ }^{-1}$ ). To control the available soil moisture, sprinkler irrigation systems have been used depending on the requirements of each nursery. Two-yearold seedlings were harvested in September 2008. From each nursery, five samples each comprising five beech seedlings, were collected using a systematic grid design with $20 \mathrm{~m}$ spacing. The samples were removed from the nursery together with the adjacent block $(18 \times 18 \times 30 \mathrm{~cm})$ of soil and transported to the laboratory in plastic bags. A total of 20 samples (100 seedlings) were analyzed. In the lab, soil and roots were separated. The root-free soil from each sample was thoroughly mixed and sieved (mesh $2 \mathrm{~mm}$ ) for the determination of $\mathrm{pH}\left(\mathrm{H}_{2} \mathrm{O}\right)$, and soil chemical analyzes. The $\mathrm{pH}$ of the soil samples was determined by mixing $20 \mathrm{ml}$ of soil with $40 \mathrm{ml}$ of deionized water. After $1 \mathrm{~h}$, the $\mathrm{pH}$ was measured with a calibrated $\mathrm{pH}$ meter equipped with a glass electrode. The total $\mathrm{N}$ and $\mathrm{C}$ contents were measured using the elemental combustion system CHNS-O (Constech Analytical Technologies Inc., Valencia, USA). The Mg, K, and $\mathrm{P}$ concentrations were measured by an ionic chromatograph Dionex 100, and a Varian BQ 20 atomic absorption spectrophotometer with a graphite cuvette.

\subsection{Ectomycorrhizal assessment}

The roots of each sample (five beech seedlings) were gently washed with tap water to remove soil and organic particles. 
The huge number of mycorrhizas present on each sample (several thousand per seedling) made assessment of morphotype abundance by counting all of the mycorrhizas impractical. Therefore, the lateral roots were removed from the main root and cut into approximately $1-\mathrm{cm}$-long small parts and placed into a Petri dish filled with water. Those small parts were randomly chosen from Petri dish, and the numbers of all active root tips colonized by each morphotype were counted, yielding approximately 1,000 mycorrhizas. For obtaining 1,000 mycorrhizas, roughly $120-150$ small parts of the lateral roots cut into pieces have been selected from each sample (five beech seedlings). Morphological typing of the ECM root tips was examined under a stereomicroscope at 10 to 60 times magnification. ECMs were separated into morphotypes based on macroscopic features (color of a mantle, type of ramification, and the presence of extramatrical hyphae, rhizomorphs, and cystidia) and referred to a database used in our Laboratory of Mycorrhizal Research, at the Institute of Dendrology (Iwański et al. 2006; Rudawska et al. 2006). The root system fragments with the same mycorrhizal morphotypes were placed in Eppendorf tubes in a cetyltrimethyl ammonium bromide buffer and kept at room temperature until processing for DNA isolation and amplification.

\subsection{Molecular identification}

Total DNA was extracted from a single ectomycorrhizal root tip using a miniprep method developed by Gardes and Bruns (1996). Three to six root tips per morphotype found in each nursery were analyzed. ECM fungi were identified by sequencing the PCR-amplified internal transcribed spacer of rDNA (ITS rDNA). DNA was amplified following the protocol of Henrion et al. (1994) and modified by Kårén et al. (1997). The reagents of the PCR reaction and their final concentrations were as follows- $20 \mathrm{mM}$ Tris- $\mathrm{HCl}$ (pH8.4), $50 \mathrm{mM} \mathrm{KCl}, 2.5 \mathrm{mM} \mathrm{MgCl}_{2}, 0.05 \% \mathrm{~W}^{-1}$ (Qiagen), $200 \mathrm{mM}$ ultra-pure dATP, dCTP, dGTP, and dTTP (Qiagen), $0.2 \mathrm{mM}$ of the two primers (ITS1F: TTGGTCATTTAGAGGAAGTAA and ITS4: TCCTCCGCTTATTGATATGC) (IBB PAN, Poland), and 1.75 units Taq DNA polymerase (Qiagen). The following thermal profile was used: $94{ }^{\circ} \mathrm{C}$ for $10 \mathrm{~min}$, then 35 cycles of $40 \mathrm{~s}$ at $92^{\circ} \mathrm{C}, 40 \mathrm{~s}$ at $57^{\circ} \mathrm{C}$ and $80 \mathrm{~s}$ at $72{ }^{\circ} \mathrm{C}$, and a final extension of $72{ }^{\circ} \mathrm{C}$ for $10 \mathrm{~min}$. To optimize PCR amplification, 1:10, 1:20, 1:40, 1:60, and 1:100 dilutions of extracted DNA templates were tested. Amplified PCR products were checked on $1.5 \%$ agarose gels with ethidium bromide under UV light. Those samples for which a definite PCR product was found were sequenced in forward and reverse directions with ITS1f and ITS4 primers, at the Laboratory of Molecular Biology of the Adam Mickiewicz University (Poznan). Using the BLASTn tool, obtained DNA sequences were aligned with sequences deposited in GenBank (http://www.ncbi.nlm.nih.gov) or UNITE (http://unite.ut.ee) databases. A positive identification of a mycorrhizal species was confirmed using the widely accepted $\geq 98 \%$ sequence similarity of the ITS region sequence. Obtained sequences were also checked for the presence of chimeras using the PlutoF application (Nilsson et al. 2009). From each nursery, the best representative of each unique ITS sequence type was deposited in GenBank (JF419481- JF419516). To more detailed assign of "uncultured" and separate closely related taxa, phylogenetic test within lineages (separately for Asco- and Basidiomycota) has been performed, using MEGA 4 software (Tamura et al. 2007).

\subsection{Data analysis}

The diversity of the ectomycorrhizas was expressed as the number of recognized ECM taxa (taxa richness). The relative abundance of each morphotype (number of root tips of each morphotype/total number of mycorrhizas) was calculated separately for each sample. The taxa richness, Shannon diversity index, evenness, and Simpson dominance index were calculated using PAST 2.13 (Hammer et al. 2001). To assess the sufficiency of the sampling effort, a taxa accumulation curve (Mao Tau), and estimators of true taxa richness (Jackknife1 and Chao2 richness estimator) were determined with the EstimateS program version 8.0 (Colwell 2006), using 100 randomized runs without sample replacement. Sampling completeness was calculated as follows: observed taxa numbers divided by estimated taxa numbers (determined by Jackknife1 or Chao2) and presented as percentage. The similarity of the ECM fungal communities between nurseries was calculated using the Bray-Curtis (BC) index (Bray and Curtis 1957) based on the number of ECM root tips of each fungal taxon in each nursery. Bray-Curtis coefficients were used in the analysis of similarity (ANOSIM) (Clarke 1993) to determine whether the ECM fungal communities differed between the analyzed nurseries. Data were standardized and square root transformed prior to analysis. The advantages of the ANOSIM test are that it does not assume any underlying distribution to the data, and avoids using the $\mathrm{BC}$ index to directly compare sets of communities. Instead, it is a nonparametric test based only on the rank order of the matrix values. ANOSIM produces an $R$ statistic that is an absolute measure of distance between groups. Large positive $R$ values (up to 1) imply dissimilarity between groups. To visualize the $\mathrm{BC}$ values, non-metric multidimensional scaling (NMDS) was used. Both ANOSIM and NMDS were performed using PAST 2.13. The soil parameters of the different nurseries were compared by analysis of variance (ANOVA) with Tukey's test. Prior to the ANOVA analysis, the data were arcsine transformed. A Spearman rank correlation was used to show relationships between: taxa richness, diversity, evenness, dominance, and soil variables. 


\section{Results}

\subsection{Soil parameters}

The measured soil parameters (N, P, K, Mg, and C) revealed a considerable variation between the tested nurseries (Table 1). The $\mathrm{C}$ and $\mathrm{N}$ contents were significantly lower in the RUN and SUSZ nurseries (2.35 and $2.31 \%$, respectively, for C; 0.10 and $0.14 \%$, respectively, for $\mathrm{N}$ ). The highest $\mathrm{N}$ content of $0.22 \%$ was found in the PRU nursery. The highest potassium content was observed in PRU (15.66\%), and differed significantly from both the PIA and RUN nurseries. The P content was significantly lower in the PIA nursery $(2.58 \%)$. The lowest $\mathrm{Mg}$ content was noted in the RUN and SUSZ nurseries (5.15 and $3.60 \%$, respectively).

\subsection{Mycorrhizal communities}

Mycorrhizal colonization was nearly $100 \%$ in all the tested beech samples. The morphological assessment of 18,842 root tips yielded 38 morphotypes. Molecular investigations revealed a total of 27 fungal taxa (Online Resources 1 and 2); of these, 7 were assigned to genera (Cadophora sp., Peziza sp., Tuber sp. 1, Tuber sp. 2, Hebeloma sp., Lactarius sp. and Tomentella sp.), and 15 were assigned to species (Cenococcum geophilum Fr. 1829, Geopora cervina (Velen.) T. Schumach. 1979, Hydnotrya tulasnei (Berk.) Berk. \& Broome 1846, Rhizoscyphus ericae (D.J. Read) W.Y. Zhuang \& Korf 2004, Tuber maculatum Vittad. 1831, Hebeloma cavipes Huijsman 1961, Hebeloma crustuliniforme (Bull.) Quél. 1872, Hebeloma sacchariolens Quél. 1880, Hymenogaster decorus Tul. \& C. Tul. 1843, Laccaria tortilis (Bolton) Cooke 1884, Naucoria salicis P.D. Orton 1960, Scleroderma citrinum Pers. 1801, Scleroderma laeve Lloyd 1916, Scleroderma verrucosum (Bull.) Pers. 1801 and Tomentella ellisii (Sacc.) Jülich \& Stalpers 1980). Additional information about the detected taxa or groups of fungi is presented as supplementary material (Online Resource 3).
Based on the sequence phylogenetic analysis of ITS region, one ECM type was designated as an uncultured Pezizales, and the next two were designated as uncultured Ascomycota and Basidiomycota (data not shown) Phylogenetic analysis of ITS sequences has also shown intragenus diversity among sequences obtained from Tuber spp. and Tomentella spp. mycorrhizas originated from different nurseries, and thus allows the discrimination of T. maculatum, Tuber sp. 1 and Tuber sp. 2 among Tuber spp. mycorrhizas; and T. ellisii and Tomentella sp. 1. among mycorrhizas of Tomentella spp. (data not shown). Two morphotypes (F9, F51) could not be amplified, but on the basis of their unique morphological features, they were assigned as separate, unidentified taxa (see Online Resources 1).

The occurrence and the mean relative abundance of each fungal taxon in particular nurseries are shown in Table 2. Only Tuber sp. 1 was noted in all nurseries. The relative abundance of this taxon ranged between $4.06 \%$ in the RUN nursery, to $34.87 \%$ in the SUSZ nursery. Other frequent taxa, present in three out of four nurseries, were Cadophora sp., C. geophilum agg., H. sacchariolens and L. tortilis. In two nurseries, N. salicis was detected. Among the three detected Sleroderma species (S. citrinum, S. leave, S. verrucosum) each one has been found in separate nursery. Depending on the nursery, different ECM fungal taxa dominated in the observed communities (Table 2). The overall taxa richness of identified ECM fungal taxa for samples of beech seedlings was variable and ranged from 6 to 13 taxa, depending on the nursery (Tables 2 and 3). A taxa curve (Sobs Mao Tau) revealed an asymptotic pattern in taxa number, with an increase in the number of samples of beech seedlings from each tested nursery (data not shown). The Jackknife1 and Chao2 estimators (Table 3), revealed that observed ECM taxa richness range from 89.6 to $96.6 \%$ of estimated richness, depending on the nursery. The highest mean taxa richness per sample of seedlings was observed in RUN (6.27), and the lowest was in PIA (2.93). The evenness index and diversity were highest in RUN ( 0.88 and 1.58 , respectively), and the highest taxa dominance index was noted in SUSZ (0.62).

Table 1 Soil parameters for the examined forest bare-root nurseries (PIA—Piaski, PRU—Prudnik, RUN—Runowo, SUSZ—Susz) (values are means, $n=5$ )

\begin{tabular}{llllrrrr}
\hline & $\mathrm{pH} \mathrm{H}+\mathrm{O}$ & $\begin{array}{l}\mathrm{C} \\
(\%)\end{array}$ & $\begin{array}{l}\mathrm{N} \\
(\%)\end{array}$ & \multicolumn{1}{c}{$\begin{array}{l}\mathrm{P} \\
(\%)\end{array}$} & \multicolumn{1}{c}{$\begin{array}{l}\mathrm{K} \\
(\%)\end{array}$} & \multicolumn{1}{c}{$\begin{array}{l}\mathrm{Mg} \\
(\%)\end{array}$} \\
\hline PIA & 5.70 & $3.17 \pm 0.81 \mathrm{~b}$ & $0.19 \pm 0.02 \mathrm{~b}$ & $2.58 \pm 0.71 \mathrm{a}$ & $7.96 \pm 0.98 \mathrm{a}$ & $15.40 \pm 1.27 \mathrm{~b}$ & 16.68 \\
PRU & 5.83 & $4.77 \pm 0.79 \mathrm{~b}$ & $0.22 \pm 0.03 \mathrm{c}$ & $24.66 \pm 1.98 \mathrm{c}$ & $15.66 \pm 1.52 \mathrm{~b}$ & $15.92 \pm 1.34 \mathrm{~b}$ & 22.25 \\
RUN & 5.75 & $2.35 \pm 0.11 \mathrm{a}$ & $0.10 \pm 0.03 \mathrm{a}$ & $9.80 \pm 1.74 \mathrm{~b}$ & $6.75 \pm 1.02 \mathrm{a}$ & $5.15 \pm 0.95 \mathrm{a}$ & 23.79 \\
SUSZ & 6.10 & $2.31 \pm 0.23 \mathrm{a}$ & $0.14 \pm 0.02 \mathrm{a}$ & $27.40 \pm 2.13 \mathrm{c}$ & $14.50 \pm 1.24 \mathrm{~b}$ & $3.60 \pm 1.09 \mathrm{a}$ & 16.86 \\
\hline
\end{tabular}

Different letters indicate significant differences between nurseries at $p<0.05$ (Tukey's test) 
Table 2 Relative abundance of mycorrhizal fungal taxa associated with European beech from four forest bare-root nurseries (PIAPiaski, PRU—Prudnik, RUN-Runowo, SUSZ-Susz)

\begin{tabular}{|c|c|c|c|c|c|}
\hline \multirow[t]{2}{*}{ Fungal taxa } & & \multicolumn{4}{|c|}{ Nursery } \\
\hline & & PIA & PRU & RUN & SUSZ \\
\hline Hebeloma sacchariolens & B & 49.05 & 8.33 & & 23.21 \\
\hline Laccaria tortilis & B & 22.98 & 0.87 & 5.88 & \\
\hline Scleroderma laeve & B & 16.26 & & & \\
\hline Tuber sp. 1 & A & 10.46 & 5.79 & 4.06 & 34.87 \\
\hline UN Basidiomycota & B & 1.13 & & & \\
\hline $\begin{array}{l}\text { Cenococcum geophilum } \\
\text { agg. }\end{array}$ & A & 0.12 & 0.47 & & 1.82 \\
\hline Hydnotrya tulasnei & A & & 43.55 & & \\
\hline F 51 & & & 13.93 & & \\
\hline Tomentella sp. & $\mathrm{B}$ & & 9.14 & & \\
\hline Scleroderma verrucosum & $\mathrm{B}$ & & 8.46 & & \\
\hline Tuber sp. 2 & $\mathrm{~A}$ & & 3.92 & & \\
\hline Cadophora sp. & $\mathrm{A}$ & & 2.84 & 4.21 & 0.39 \\
\hline Naucoria salicis & $\mathrm{B}$ & & 2.27 & 18.28 & \\
\hline Hebeloma cavipes & $\mathrm{B}$ & & 0.32 & & \\
\hline Hymenogaster decorus & $\mathrm{B}$ & & 0.11 & & \\
\hline Hebeloma crustuliniforme & B & & & 18.43 & \\
\hline Peziza sp. & A & & & 16.94 & \\
\hline F 9 & & & & 15.52 & \\
\hline Tuber maculatum & A & & & 12.84 & \\
\hline Hebeloma sp. & B & & & 2.38 & \\
\hline Geopora cervina & A & & & 0.93 & \\
\hline Tomentella ellisii & $\mathrm{B}$ & & & 0.52 & \\
\hline Scleroderma citrinum & $\mathrm{B}$ & & & & 11.34 \\
\hline UN Pezizales & A & & & & 8.09 \\
\hline Rhizoscyphus ericae & A & & & & 7.08 \\
\hline Lactarius sp. & B & & & & 6.71 \\
\hline UN Ascomycota & $\mathrm{A}$ & & & & 6.49 \\
\hline
\end{tabular}

$A$ Ascomycota, $B$ Basidiomycota

According to the ANOSIM analysis, ECM fungal communities differed significantly between nurseries (global $R=$ $0.7741, p<0.0001)$. NMDS ordination of the four ECM fungal assemblages consistently separated the tested nurseries (Fig. 1). The Spearman's rank correlation revealed that the Shannon diversity and Simpson dominance index were positively correlated with the level of $\mathrm{K}(R=0.46$ and $R=$ 0.50 , respectively, $p \leq 0.05)$. Evenness was positively correlated with $\mathrm{P}$ content $(R=0.46, p \leq 0.05)$, but negatively correlated with soil $\mathrm{pH}(R=-0.59, p \leq 0.01)$.

\section{Discussion}

To our knowledge, this is the first detailed estimation of ECM diversity of $F$. sylvatica seedlings in bare-root nursery
Table 3 Shannon-Wiener diversity, evenness, Simpson dominance indices, taxa richness, Jackknife1 and Chao 2 richness estimators and sampling completeness of ectomycorrhizal communities associated with samples of European beech seedlings in four forest bareroot nurseries (PIA-Piaski, RUN-Runowo, PRU-Prudnik, SUSZ-Susz)

\begin{tabular}{lcccc}
\hline & PIA & PRU & RUN & SUSZ \\
\hline Diversity & 0.70 & 1.13 & 1.58 & 0.73 \\
Evenness & 0.72 & 0.64 & 0.88 & 0.56 \\
Dominance & 0.57 & 0.46 & 0.24 & 0.62 \\
Average taxa richness & 2.93 & 5.73 & 6.27 & 3.93 \\
Total taxa richness & 6 & 13 & 11 & 9 \\
Jackknife1 & 6.70 & 14.29 & 11.92 & 9.95 \\
Sampling completness & 89.6 & 91.0 & 92.3 & 90.4 \\
$\quad$ (Jackknife1) & 6.37 & 13.70 & 11.89 & 9.32 \\
Chao2 & 94.2 & 94.9 & 92.5 & 96.6 \\
Sampling completness & & & & \\
$\quad$ (Chao2) & & & &
\end{tabular}

conditions. Our findings add to the evidence of a growing number of symbionts being able to colonize seedlings in nursery conditions, and emphasize the elucidation potential of molecular tools for detailed descriptions of ECM communities in different environments. Some of the identified fungi (Cenococcum, Tuber, Hebeloma, Laccaria) have been previously noted in forest nurseries as ECM symbionts of coniferous (Menkis et al. 2005; Rudawska et al. 2006; Leski et al. 2008; Menkis and Vasaitis 2011) or deciduous hosts (Leski et al. 2010), but some of them have been found for the first time in nursery conditions (Hydnotrya, Hymenogaster, Lactarius), or even as mycorrhizal partners of European beech (Naucoria, Geopora). For more details about the detected ECM fungi, see Online Resource 3.

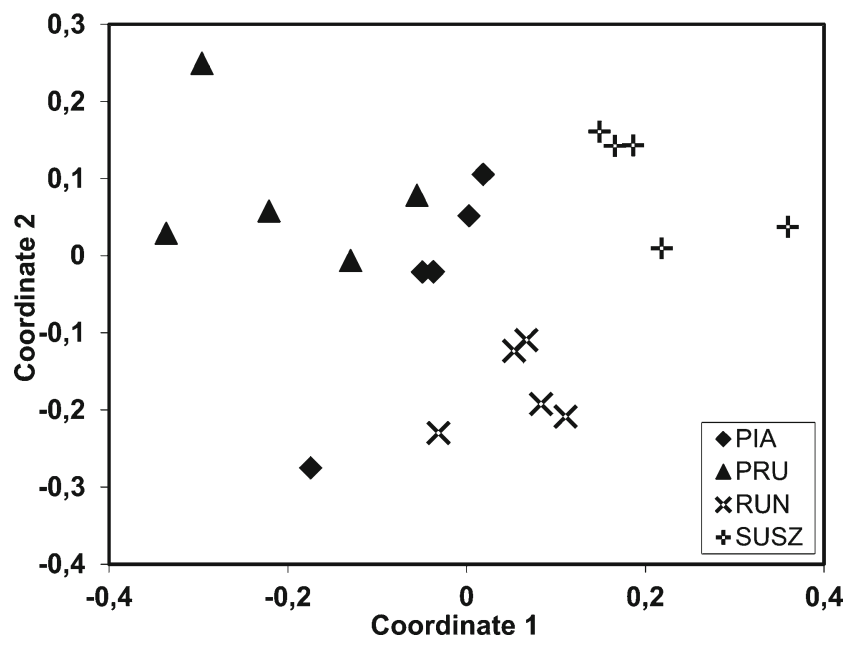

Fig. 1 NMDS (non-metric multidimensional scaling) ordination of ECM fungal communities on European beech from four tested forest nurseries (PIA Piaski, PRU Prudnik, RUN Runowo, SUSZ Susz) 
We discovered 27 taxa of ECM fungi on 2-year-old beech seedlings from four bare-root nurseries. The number of recognized taxa was richer than for conifers (Scots pine, Norway spruce, and European larch) and small-leaved lime (Menkis et al. 2005; Iwański et al. 2006; Rudawska et al. 2006; Leski et al. 2008; Timonen and Kauppinen 2008), but comparable with pedunculate and sessile oak (Leski et al. 2010) grown in nursery conditions.

Taxa richness in individual nurseries ranged from 6 to 13, and is a characteristic feature of each nursery rather than a methodological bias causing underestimation. This was confirmed by the taxa accumulation curve (data not presented) for each analyzed nursery, and the taxa estimators (Table 3 ) that indicated that we had sampled sufficiently and observed taxa richness to truly reflect the real assemblage of ECM fungi being able to colonize beech seedlings in each nursery. Twenty-seven identified taxa belonged to either Ascomycota or Basidiomycota. The respective contributions of Asco- or Basidiomycota to communities of ECM fungi differed in terms of taxa composition, richness, and relative abundance, depending on the nursery. Of the 27 recognized fungal taxa, only 6 were found in more than one nursery. The occurrence of ECM fungi in nurseries with a frequency of only one agrees with the findings of studies carried out by Leski et al. (2010) on European oak seedlings, and supports our concept that each nursery had a unique structure of ECM assemblages. This is further confirmed by the ANOSIM and NMDS analyzes that have clearly shown that ECM fungal communities differed significantly between the nurseries (Fig. 1). We presume that the uniqueness of each bareroot nursery is a result of cultural practices (soil management, seedbed preparation, irrigation and fertilization, pest and weed control, root wrenching, transplanting, etc.) and environmental factors (age and locality of the nursery, tree species' composition of surrounding forests, local microclimate, crop rotation cycles, etc.). In our investigation, significant differences in soil $\mathrm{C}, \mathrm{N}, \mathrm{P}, \mathrm{K}$, and $\mathrm{Mg}$ content among the tested nurseries were noted (Table 1), as a result of the individual fertility management of each nursery. Significant relationships between ecological indices and soil parameters ( $\mathrm{pH}, \mathrm{P}$ and $\mathrm{K}$ ) were found, and are areas of research that warrant further work, but were beyond the scope of our study. ECM colonization patterns of an individual nursery can also be driven by differences in the propagule dispersal of each ECM fungus. In specific forest nursery conditions where seedlings grow beyond the mycorrhizal network of the mature trees, the initial source of mycorrhizal inoculum is mainly limited to the fungal spores. The dispersal mode of each fungal taxa is strongly dependent on the epigeous and hypogeous habit of fruiting body production. Epigeous fruiting taxa produce airborne spores, and can therefore disperse over far greater distances than hypogeous fruiting taxa, whose dispersal vectors are often small mammals with rather limited home ranges (Wolfe et al. 2009). In addition to the identification of the typical airborne-dispersing epigeous genera (Hebeloma, Laccaria, Scleroderma, Peziza), our findings detected at least a few hypogeous genera (Hydnotrya, Hymenogaster, Tuber). The fruiting bodies of the latter have not been observed in nursery beds and thus we may assume that the primary source of the inoculum for these genera being fungal spores from the surrounding forest, possibly spread to nurseries on animal feces. The dispersal of ECM inocula on the fecal pellets of small rodents has been detected at distances up to $35 \mathrm{~m}$ from trees where the fruiting bodies occurred (Frank et al. 2009). ECM inoculum in forest nurseries may also originate from forest litter, which is occasionally used in nursery management practices as a source of organic matter and for improvement of the physical characteristics of the soil. Indeed, in our study, the highest ECM taxa richness has been observed in a nursery (PRU) where forest litter addition is practiced.

In conclusion, as noted for beech and other forest tree species (Menkis et al. 2005; Iwański et al. 2006; Rudawska et al. 2006; Leski et al. 2008, 2010; Timonen and Kauppinen 2008), ECM fungal communities in forest bare-root nurseries are fairly diverse and the level of colonization of seedlings is very high. We therefore agree with the opinion of Southworth et al. (2009) that artificial inoculation in general is not necessary in nursery practice. This is confirmed by the successful growth and development of nursery seedlings after outplanting (author's personal observation).

Acknowledgements This study was supported by Institute of Dendrology Polish Academy of Sciences. We thank the Board of State Forest Districts in Olsztyn, Toruń, Poznań and Katowice and forest nursery staffs for the supply of experimental material and their help with fieldwork and in assembling background information.

Open Access This article is distributed under the terms of the Creative Commons Attribution License which permits any use, distribution, and reproduction in any medium, provided the original author(s) and the source are credited.

\section{References}

Agerer $R$ (1987-2008) Colour Atlas of Ectomycorrhizae. 1st to 11th ed. Einhorn-Verlag Eduard Dietenberger, SchwäbischGmünd

Bray JR, Curtis JT (1957) An ordination of the upland forest communities of southern Wisconsin. Ecol Monogr 27:325-349

Buée M, Vairelles D, Garbaye J (2005) Year-round monitoring of diversity and potential metabolic activity of the ectomycorrhizal community in a beech (Fagus sylvatica) forest subjected to two thinning regimes. Mycorrhiza 15:235-245. doi:10.1007/s00572004-0313-6

Clarke KR (1993) Non-parametric multivariate analyses of changes in community structure. Aus J Ecol 18:117-143

Colwell RK (2006) EstimateS: Statistical estimation of species richness and shared species from samples. Version 8.0 User's Guide and application persistent at: http://purl.oclc.org/estimates 
Dahlberg A, Stenström E (1991) Dynamic changes in nursery and indigenous mycorrhiza of Pinus sylvestris seedlings planted out in forest and clearcuts. Plant Soil 136:73-86. doi:10.1007/BF02465222

Diekmann M, Eilertsen O, Fremstad E, Lawesson EJ, Aude E (1999) Beech forest communities in the Nordic countries - a multivariate analysis. Plant Ecol 140:203-220

Dominik T (1957) Badania mykotrofizmu zespołów buka nad Bałtykiem. Ekol Pol 7:213-256 (in polish with French summary)

Dominik T, Boullard B (1961) Mycotrophism of beeches in France. Preliminary investigations. Prace Inst Badaw Les 207:3-30

Druebert C, Lang C, Valtenen K, Polle A (2009) Beech carbon productivity as driver of ectomycorrhizal abundance and diversity. Plant Cell Environ 32:992-1003. doi:10.1111/j.1365-3040.2009.01983.x

Frank AB (1885) Über die auf Wurzelsymbiose beruhende Ernährung gewisser Bäume durch unterirdische Pilze. Ber Dtsch Bot Ges 3:128-145

Frank JL, Anglin S, Carrington EM, Taylor DS, Viratos B, Southworth D (2009) Rodent dispersal of fungal spores promotes seedling establishment away from mycorrhizal networks on Quercus garryana. Botany 87:821-829. doi:10.1139/B09-044

Gardes M, Bruns TD (1996) ITS-RFLP matching for identification fungi. Meth Mol Biol 50:177-186

Grebenc T, Christensen M, Vilhar U, Čater M, Martín MP, Simončič P, Kraigher H (2009) Response of ectomycorrhizal community structure to gap opening in natural and managed temperate beech-dominated forests. Can J For Res 39:1375-1386. doi:10.1139/X09-129

Grebenc T, Kraigher H (2007) Changes in the community of ectomycorrhizal fungi and increased fine root number under adult beech trees chronically fumigated with double ambient ozone concentration. Plant Biol 9:279-287. doi:10.1055/s-2006-924489

Hammer O, Harper DAT, Ryan PD (2001) PAST: Palaeontological statistics software package for education and data analysis. Palaeont Electron 4:9

Harley JL (1959) The biology of mycorrhizas, Plant Sci Monogr. Leonard Hill, London

Henrion B, Di Battista C, Bouchard D, Vairelles D, Thompson BD, Le Tacon F, Martin F (1994) Monitoring the persistance of Laccaria bicolor as an ectomycorrhizal symbiont of nursery-grown Douglas fir by PCR of the rDNA intergenic spacer. Mol Ecol 3:571580. doi:0.1111/j.1365-294X.1994.tb00088.x

Iwański M, Rudawska M, Leski T (2006) Mycorrhizal associations of nursery grown Scots pine (Pinus sylvestris L.) seedlings in Poland. Ann For Sci 63:715-723. doi:10.1051/forest:2006052

Jones MD, Durall DM, Cairney JWG (2003) Ectomycorrhizal fungal communities in young forest stands regenerating after clearcut logging. New Phytol 157:399-422. doi:10.1046/j.14698137.2003.00698.x

Kårén O, Hogber N, Dahlberg A, Jonsson L, Nylund JE (1997) Interand intraspecific variation in the ITS region of rDNA of ectomycorrhizal fungi in Fennoscandia as detected by endonuclease analysis. New Phytol 136:313-325. doi:10.1046/j.1469-8137.1997.00742.x

Leski T, Aučina A, Rudawska M (2008) The ectomycorrhizal status of European larch (Larix decidua Mill.) seedlings from bare-root forest nurseries. For Ecol Manag 256:2136-2144. doi:10.1016/ j.foreco.2008.08.004

Leski T, Pietras M, Rudawska M (2010) Ectomycorrhizal fungal communities of pedunculate and sessile oak seedlings from bare-root forest nurseries. Mycorrhiza 20:179-190. doi:10.1007/s00572-009-0278-6

Menkis A, Vasaitis R (2011) Fungal in roots of nursery grown Pinus sylwestris ectomycorrhizal colonization, genetic and spatial distribution. Microb Ecol 61:52-63. doi:10.1007/s00248-010-9676-8
Menkis A, Vasiliauskas R, Taylor AFS, Stenlid J, Finlay R (2005) Fungal communities in mycorrhizal roots of conifer seedlings in forest nurseries under different cultivation systems, assessed by morphotyping, direct sequencing, and mycelial isolation. Mycorrhiza 16:33-41. doi:10.1007/s00572-005-0011-z

Meyer FH (1973) Distribution of ectomycorrhizae in native and manmade forests. In: Marks GC, Kozlowski TT (eds) Etomycorrhizae. Their ecology and physiology. Academic, London, pp 79-105

Moosmayer HU (2002) Langfristige regionale Waldbauplannung in Baden-Württemberg-Grundlagen und Ergebnisse. Landesforstverwaltung Baden Württemberg, Stuttgart

Nilsson H, Abarenkov K, Veldre V, Nylinder S, De Wit P, Brosche S, Ryberg M, Kristianson E (2009) An open source chimera checker for the fungal ITS region. Mol Ecol Res 10:1076-1081. doi:10.1111/j.1755-0998.2010.02850.x

Pena R, Offermann C, Simon J, Naumann PS, Geßler A, Holst J, Dannenmann M, Mayer H, Kögel-Knabner I, Rennenberg H, Polle A (2010) Gridling affects ectomycorrhizal fungal (EMF) diversity and reveals functional differences in EMF community composition in a beech forest. Appl Environ Microbiol 76:18311841. doi:10.1128/AEM.01703-09

Perry DA, Molina R, Amaranthus MP (1987) Mycorrhizae, mycorrhizospheres, and reforestation; current knowledge and research needs. Can J For Res 17:929-940

Pritsch K, Esperschütz J, Haesler F, Raidl S, Winkler JB, Schloter M (2009) Structure and activities of ectomycorrhizal and microbial communities in the rhizosphere of Fagus sylvatica under ozone and pathogen stress in a lysimeter study. Plant Soil 323:97-109. doi:10.1007/s11104-009-9972-6

Rudawska M, Leski T (2009) The significance of knowledge about ectomycorrhizal fungal community in bare-root nurseries for artificial inoculation. Sylwan 153:16-26 (in polish with English abstract)

Rudawska M, Leski T, Trocha LK, Gornowicz R (2006) Ectomycorrhizal status spruce seedlings from bare-root forest nurseries. For Ecol Manag 236:375-384. doi:10.1016/j.foreco. 2006.09.066

Southworth D, Carrington EM, Frank JL, Gould P, Harrington CA, Davine WD (2009) Mycorrhizas on nursery and field seedlings of Quercus garryana. Mycorrhiza 19:149-158. doi:10.1007/s00572008-0222-1

Tamura K, Dudley J, Nei M, Kumar S (2007) MEGA4: Molecular Evolutionary Genetics Analysis (MEGA) software version 4.0. Mol Biol Evol 24:1596-1599. doi:10.1093/molbev/msm092

Timonen S, Kauppinen P (2008) Mycorrhizal colonization patterns of Tilia trees in street, nursery, and forest habitats in southern Finland. Urban For Urban Green 7:265-276. doi:10.1016/ j.ufug.2008.08.001

Voiry H (1981) Classification morphologique des ectomycorhizes du chêne et du hêtre dans le nord-est de la France. Eur J For Pathol 11:284-299

Wolfe BE, Parrent JL, Koch AM, Sikes BA, Gardes M, Klironomos JN (2009) Spatial heterogeneity in mycorrhizal populations and communities: scales and mechanisms. In: Azcon-Aguilar C, Barea JM, Gianinazzi S, Gianinazzi-Pearson V (eds) MycorrhizasFunctional processes and ecological impact. Springer, Berlin, pp $167-185$

Železnik P, Hrenko M, Then C, Koch N, Grebenc T, Levanič T, Kraigher H (2007) CASIROZ: Root parameters and types of ectomycorrhiza of young beech plants exposed to different ozone and light regimes. Plant Biol 9:298-308. doi:10.1055/ s-2006-955916 